\title{
Knowledge towards Zika among medical students, interns and general practitioners in Indonesia: A cross-sectional study in Aceh
}

\author{
Harapan Harapan ${ }^{\mathrm{a}, \mathrm{b}, \mathrm{c}, *}$, Mudatsir Mudatsir ${ }^{\mathrm{a}, \mathrm{b}, \mathrm{c}, * *}$, Rosaria Indah $^{\mathrm{d}, \mathrm{e}}$, Prattama S. Utomo ${ }^{\mathrm{f}}$, \\ Samsul Anwar ${ }^{\mathrm{g}}$, Nur Wahyuniati ${ }^{\mathrm{a}}$, Reza Maulana ${ }^{\mathrm{a}}$, Ichsan Ichsan ${ }^{\mathrm{a}, \mathrm{b}}$, Alma Aletta ${ }^{\mathrm{h}}$, Ikram Ikram ${ }^{\mathrm{a}}$, \\ Muhammad R. Ramadana ${ }^{a}$, Yogambigai Rajamoorthy ${ }^{i}$, Abdul M. Setiawan ${ }^{j}$, Abram L. Wagner $^{\mathrm{k}}$, \\ Mohd Andalas,
}

${ }^{a}$ Medical Research Unit, School of Medicine, Syiah Kuala University, Banda Aceh, Indonesia

${ }^{\mathrm{b}}$ Department of Microbiology, School of Medicine, Syiah Kuala University, Banda Aceh, Indonesia

${ }^{\mathrm{c}}$ Tropical Disease Centre, School of Medicine, Syiah Kuala University, Banda Aceh, Indonesia

${ }^{\mathrm{d}}$ Medical Education Unit, School of Medicine, Syiah Kuala University, Banda Aceh, Indonesia

${ }^{\mathrm{e}}$ Sydney School of Education and Social Work, Faculty of Arts and Social Sciences, The University of Sydney, Sydney, Australia

${ }^{\mathrm{f}}$ Department of Medical Education, Faculty of Medicine, Gadjah Mada University, Jogjakarta, Indonesia

${ }^{g}$ Department of Statistics, Faculty of Mathematics and Natural Sciences, Syiah Kuala University, Banda Aceh, Indonesia

${ }^{\mathrm{h}}$ Department of Family Medicine, School of Medicine, Syiah Kuala University, Banda Aceh, Indonesia

${ }^{\mathrm{i}}$ Universiti Tunku Abdul Rahman, Selangor, Malaysia

${ }^{\mathrm{j}}$ Department of Microbiology, Faculty of Medicine and Health Sciences, State Islamic University of Maulana Malik Ibrahim, Malang, Indonesia

${ }^{\mathrm{k}}$ Department of Epidemiology, University of Michigan, Michigan, USA

${ }^{1}$ Department of Obstetrics and Gynecology, School of Medicine, Syiah Kuala University, Banda Aceh, Indonesia

\section{A R T I C L E I N F O}

\section{Keywords:}

Zika

Zika infection

Knowledge

Healthcare worker

Medical student

\begin{abstract}
A B S T R A C T
Background: The aim of this study was to assess the level of knowledge towards Zika among medical students, medical interns and general practitioners (GPs) in Indonesia.

Methods: A cross-sectional study was conducted in Aceh province of Indonesia in 2016. A set of validated questionnaire, consisting 24 questions, was used to assess the knowledge. Logistic regression was used to estimate the differences in knowledge between groups.

Results: A total of 1031 participants were included in the final analysis in which most of them were medical student (39.7\%), followed by GPs (37.7\%) and medical intern (22.6\%). Approximately 17\%, 19\%, and 64\% of the medical students, interns and GPs had good knowledge, respectively. The knowledge level of medical student and medical interns was roughly equivalent. Medical students and medical interns had significantly lower odds of having a good knowledge compared to GPs, OR: 0.12 (95\%CI: 0.08-0.16) and OR: 0.13 (95\%CI: 0.09-0.20), respectively.

Conclusion: General practitioners have greater knowledge of Zika than medical students or interns, possibly as a result of clinical experiences or exposure to learning. Inclusion of Zika learning materials in the national medical curriculum could improve knowledge of Zika and the ability of the health care workforce to respond to future outbreaks.
\end{abstract}

\section{Introduction}

First reported in humans in Nigeria in $1954,{ }^{1}$ Zika outbreaks have more recently been reported in Oceanian countries since $2007^{2,3}$ and in the Americas since 2014. ${ }^{4-6}$ On February 1, 2016, the World Health Organization (WHO) declared Zika as a public health emergency of international concern, and as of March 10, 2017, 31 countries and territories have reported microcephaly and/or central nervous system malformation cases potentially associated with Zika. ${ }^{6}$ No Zika cases have been reported in Indonesia so far, but serology studies, ${ }^{7,8}$ case reports from travellers ${ }^{9,10}$ and molecular virology studies ${ }^{11,12}$ provide evidence that Zika virus is present in the country.

\footnotetext{
* Corresponding author. Medical Research Unit, School of Medicine, Syiah Kuala University, Jl. T. Tanoeh Abe, Darussalam, Banda Aceh, 23111, Indonesia.

${ }^{* *}$ Corresponding author. Medical Research Unit, School of Medicine, Syiah Kuala University, Jl. T. Tanoeh Abe, Darussalam, Banda Aceh, 23111, Indonesia.

E-mail addresses: harapan@unsyiah.ac.id (H. Harapan), mudatsir@unsyiah.ac.id (M. Mudatsir).
} 
After Zika was declared a public health emergency, studies assessing knowledge of Zika were conducted among medical ${ }^{13-18}$ and non-medical university students. ${ }^{18,19}$ However, no study has been done in a Southeast Asian country. Previously, we conducted studies related to knowledge of Zika among general practitioners (GPs) in Indonesia, and found that the knowledge level among GPs is relatively low. ${ }^{20,21}$ Therefore, strategies or programs that enhance GPs' knowledge of Zika are needed to be implemented in Indonesia. One such program with a long-term effect would be to include the prevention and management of Zika in the official medical curricula. ${ }^{20,21}$

To support that recommendation, we assessed knowledge of Zika among medical students, medical interns and GPs in Indonesia using Aceh province as a model. Aceh province was selected because this province has previously been the location for other population studies related to ZIKV infection. ${ }^{20-24}$ In addition, both public and private medical school and medical teaching hospital exist in the province. By including three different levels within the medical education system of Indonesia, this study sought to provide evidence of the effectiveness of the current curricula used in medical schools to increase knowledge of Zika.

\section{Materials and methods}

\subsection{Study design and study participants}

A cross-sectional study was conducted in Aceh province of Indonesia in 2016. Study participants were medical students, medical interns and registered GPs in Aceh province, Indonesia. Based on the conservative assumption that $50 \%$ of participants would have good knowledge on Zika, with a confidence interval of $95 \%$ and a $5 \%$ margin of error, the minimum sample size required was 303,190 , and 339 for medical student, medical intern and GP, respectively. The participants were selected as a convenience sample from universities or hospitals in Aceh.

\subsection{Study instrument}

A questionnaire was developed based on existing facts from the United States Centers for Disease Control and Prevention (CDC), and included 24 questions about Zika epidemiology, causative agent, transmission, signs and symptoms, complications, management and prevention. ${ }^{5}$ The questions were translated into Bahasa Indonesia (national language), and a panel consisting of two medical microbiologists was appointed to evaluate the validity of the content. A reliability test of questionnaires was conducted among 30 participants prior the study and Cronbach's alpha score more than 0.70 was used to indicate a good internal consistency. The data from this pilot study were excluded from the final analysis.

\subsection{Data collection}

The participants were approached by a member of the investigator team and the study purpose was explained. After obtaining consent from the participants, the questionnaire was administered. Participants were allowed to ask the investigator team to clarify any question.

\subsection{Statistical analysis}

For statistical analysis, the level of knowledge was dichotomized into "good" and "poor" based on a 75\% cut-off point of the total score (i.e., 19 out of 24). Previous literature has used a similar cut-off point of either $80 \%$ or $75 \% .^{20,22}$ This cut-off point was used to synchronize our study with a larger study related to knowledge and attitude towards pregnancy-related complications of ZIKV infection among GPs in Indonesia. $^{21}$ The differences in the knowledge level between the groups were assessed using logistic regression. Chi-square test was employed to assess the association between respondents' group and the correct answer for each question. The estimated odds ratios (ORs) were interpreted in relation to a reference category (R) and significance was assessed at $\alpha=0.05$. All analyses were conducted using Statistical Package of Social Sciences 17.0 software (SPSS Inc., Chicago, IL, USA).

\subsection{Ethical consideration}

The protocol of this study was reviewed and approved by the Ethical Clearance Committee of the School of Medicine, Syiah Kuala University (322/KE/FK/2015). Participation in this study was voluntary and participants received no incentive.

\section{Results}

We approached 1084 participants and 1069 participants were completed the interview ( $98.3 \%$ of participation rate). Among those who completed the interview, 38 data were excluded due to incomplete information, leaving a total of 1031 out of 1084 (95.1\%) participants in the final analysis. Participants were medical students (39.7\%), GPs (37.7\%) or medical interns (22.6\%). A majority of the participants were female: $74.8 \%$ of medical students, $67.4 \%$ of medical interns and $58.9 \%$ of GPs. The mean age of medical students was 19.38 (SD \pm 1.4 ) years and the mean age of medical interns was 22.9 ( $\mathrm{SD} \pm 1.33$ ) years.

Approximately $64 \%$ of the GPs had a good knowledge of Zika (Table 1 ). However, only $16.9 \%$ and $18.9 \%$ of the medical students and medical interns had good knowledge, respectively. The difference in the level of knowledge between medical students and medical interns was not statistically significant (Table 1). However, GPs had higher odds of having good knowledge of Zika compared to medical students (OR: 8.67; 95\%CI: 6.22-12.07, $P<0.001$ ). In addition, compared to GPs, the odds of having good knowledge was lower among medical interns (OR: 0.13 ; 95\%CI: $0.09-0.2, P<0.001$ ). The distribution of answers among medical students, interns and GPs for each question is presented in Table 2.

\section{Discussion}

Recent serology and molecular virology studies have indicated that Zika virus is present within Indonesia, and the medical education system has not yet included Zika in its curriculum. Our present study was conducted to compare the level of knowledge of Zika among medical students, medical interns and GPs in Aceh province of Indonesia. Aceh was selected based on some rationales: a) intensive studies related to Zika have been conducted in the Aceh province ${ }^{20-24}$

Table 1

Comparison of knowledge of Zika among medical students $(n=409)$, medical interns $(n=233)$ and general practitioners $(n=389)$ in Aceh, Indonesia (good $v s$. poor).

\begin{tabular}{|c|c|c|c|}
\hline Group & Good knowledge $n(\%)$ & OR $(95 \% \mathrm{CI})$ & $P$-value \\
\hline Medical students vs. GPs (R) & 69 (16.9) vs. 248 (63.8) & $0.12(0.08-0.16)$ & $<0.001$ \\
\hline Medical interns vs. GPs (R) & 44 (18.9) vs. $248(63.8)$ & $0.13(0.09-0.20)$ & $<0.001$ \\
\hline Medical interns $v s$. Medical students (R) & 69 (16.9) vs. 44 (18.9) & $1.15(0.76-1.74)$ & 0.520 \\
\hline
\end{tabular}

CI: confidence interval, GP: general practitioner, OR: odds ratio, R: Reference group. 
Table 2

Knowledge of Zika among medical students $(n=409)$, medical interns $(n=233)$ and general practitioners $(n=389)$ in Aceh, Indonesia.

\begin{tabular}{|c|c|c|c|c|}
\hline \multirow[t]{2}{*}{ Questions } & \multicolumn{3}{|l|}{ Correct response, $n(\%)$} & \multirow[t]{2}{*}{$P$-value } \\
\hline & General practitioners & Medical interns & Medical students & \\
\hline Zika disease is caused by viral infection & $385(99.0)$ & $218(93.6)$ & $388(94.9)$ & 0.001 \\
\hline Zika disease is caused by bacterial infection & $384(98.7)$ & $208(89.3)$ & $359(87.8)$ & $<0.001$ \\
\hline Zika disease is caused by genetic disorder & $365(93.8)$ & $203(87.1)$ & $315(77.0)$ & 0.001 \\
\hline Zika virus outbreaks occurred only in areas of Asia & $331(85.1)$ & $146(62.7)$ & $279(68.2)$ & $<0.001$ \\
\hline Zika virus is transmitted to people primarily through the bite of an infected mosquitoes & $371(95.4)$ & $185(79.4)$ & $353(86.3)$ & $<0.001$ \\
\hline Zika virus is transmitted to people primarily through the bite of an infected fly & $352(90.5)$ & $186(79.8)$ & $282(68.9)$ & $<0.001$ \\
\hline Zika virus is transmitted to people primarily through the bite of an infected Culex and Aedes mosquitoes & $52(13.4)$ & $68(29.2)$ & $102(24.9)$ & $<0.001$ \\
\hline A pregnant woman already infected with Zika virus can pass Zika virus to her foetus during pregnancy & $346(88.9)$ & $174(74.7)$ & $374(91.4)$ & $<0.001$ \\
\hline A mother can pass Zika virus to her child through breastfeeding & $290(74.6)$ & $119(51.1)$ & $106(25.9)$ & $<0.001$ \\
\hline There have been few reports of Zika cases in Indonesia & $283(72.8)$ & $171(73.4)$ & $315(77.0)$ & 0.343 \\
\hline Most people infected with Zika virus will show symptoms & $94(24.2)$ & $64(27.5)$ & $75(18.3)$ & 0.019 \\
\hline One of the common symptoms of Zika is fever & $378(97.2)$ & $201(86.3)$ & $373(91.2)$ & $<0.001$ \\
\hline One of the common symptoms of Zika is joint pain & $355(91.3)$ & $192(82.4)$ & $354(86.6)$ & 0.009 \\
\hline One of the common symptoms of Zika is diarrhoea & $288(74.0)$ & $95(40.8)$ & $141(34.5)$ & $<0.001$ \\
\hline There is vaccine available against Zika virus at this moment & $322(82.8)$ & $160(68.7)$ & $277(67.7)$ & $<0.001$ \\
\hline $\begin{array}{l}\text { Zika can be treated with plenty of rest, drink water to prevent dehydration and symptomatic medication } \\
\text { such as paracetamol to reduce fever }\end{array}$ & $372(95.6)$ & $182(78.1)$ & $318(77.8)$ & $<0.001$ \\
\hline Antimicrobial drugs is required for Zika infection & $352(90.5)$ & $174(74.7)$ & 204 (49.9) & $<0.001$ \\
\hline Serologic test of Zika virus IgM Antibodies in patient with fever is needed to confirm a Zika infection & $175(45.0)$ & $56(24.0)$ & $64(15.6)$ & $<0.001$ \\
\hline $\begin{array}{l}\text { The usage of Insect repellents, Long-sleeved shirts, long pants, and mosquito netting can prevent Zika } \\
\text { infection }\end{array}$ & $379(97.4)$ & $193(82.8)$ & $368(90.0)$ & $<0.001$ \\
\hline Zika infection during pregnancy can cause foetuses to have a birth defect & $363(93.3)$ & $178(76.4)$ & $349(85.3)$ & 0.000 \\
\hline $\begin{array}{l}\text { Zika infection during pregnancy can cause foetuses to have a birth defect of the Hearth called Ventricular } \\
\text { Septal Defect (VSD) }\end{array}$ & $252(64.8)$ & $114(48.9)$ & $144(35.2)$ & 0.000 \\
\hline Zika infection during pregnancy can cause foetuses to have a birth defect of the brain called microcephaly & $355(91.3)$ & $180(77.3)$ & $329(80.4)$ & 0.000 \\
\hline There is no laboratory test available that can confirm a Zika infection & $251(64.5)$ & $136(58.4)$ & $231(56.5)$ & 0.058 \\
\hline The detection of Zika virus IgM antibodies in serum can be used to confirm a Zika infection & $320(82.3)$ & $170(73.0)$ & 357 (87.3) & 0.000 \\
\hline
\end{tabular}

and focusing our study in the same location will provide more comprehensive data; b) both public and private medical schools and teaching hospital exist in the province; and c) each of medical school in Indonesia adopts the same National Medical Education Curriculum, and therefore, Aceh might enough to reflex national figure.

Our present study in Aceh found that GPs have better knowledge of Zika compared to either medical students or interns, and that the knowledge level of these latter two groups is roughly equivalent. These findings are interesting because, according to the existing medical curricula in Indonesia, no group would have received Zika information during their studies. All received their medical education from national curricula derived from the 2006 National General Practitioner Competence List, ${ }^{25}$ in which Zika was not listed as a compulsory disease. In addition, the Standard Competence of General Practitioner that had been released and regulated by the Ministry of Education of Indonesia (Indonesian Medical Council, 2014) has not mentioned Zika as a particular subject for a learning objective. Accordingly, knowledge of Zika is not distributed as a mandatory subject for medical doctor graduates in Indonesia. The lack of medical training in Zika could be a plausible explanation for why medical students and interns' knowledge of Zika was less compared to GPs. Students and interns did not receive any Zika related-knowledge or training during their medical education and training, and so would have a similar level of knowledge about Zika. Lack of prior knowledge of Zika could lead to poor acquisition of further knowledge and lack of retainment of future knowledge. ${ }^{26}$

The question remains for how GPs gain their knowledge of Zika. Previously, study have revealed that $60.5 \%$ of GPs in Java and Sumatra islands of Indonesia had good knowledge of issues relating to pregnancy and Zika. ${ }^{21}$ Furthermore, GPs may have better measured-knowledge since they have been practising medicine longer than medical interns and medical students. Thus, GPs may have been exposed to more experiences than other groups. This phenomenon is consistent with the principle of experiential learning in medicine, where medical practitioners who have more experience or exposure may have a better understanding and comprehension of particular knowledge or skills. ${ }^{27}$ Robust clinical experience has been reported to increase measures of medical knowledge. ${ }^{28}$ Another plausible explanation that can be discerned from the relatively good knowledge of the GPs is that GPs have accessed better information sources. For instance, the Ministry of Health's official website has posted information regarding Zika and one particular post regarding frequently asked questions around Zika infection has been read by more than 15.000 readers since it was initially released. ${ }^{29}$ GP's knowledge about Zika could come from this government information source or from workshops, conferences and other internet-based information.

GPs in Indonesia need to continuously update their knowledge and skills to keep their licence, based on regulations from the Indonesian Medical Council, which are mandated by the president of the Republic of Indonesia and the parliament. ${ }^{30}$ One of the most important source for updating GPs' knowledge on Zika, is from Continuing Medical Education (CME) which incorporates workshops and conferences, reporting, and online interaction. To increase GPs' knowledge of Zika trough CME, some strategies are need: (a) the provision of high quality, reliable and applicable information from official sources; (b) promoting learning of information-seeking skills; and (c) encouraging GPs to attend interactive workshops and conferences as part of the CME program. ${ }^{31,32}$ These strategies should be employed while advocating for the incorporation of Zika into the standard of medical competence which is regulated by the Indonesian Medical Council.

\section{Conclusion}

In conclusion, this study was conducted to provide evidence for the level of knowledge among GPs, medical students and medical interns in Indonesia. We found that the current medical curriculum in medical schools in Indonesia does not increase knowledge of Zika. Rendering medical education about Zika is highly important and relevant for prevention and control efforts of Zika. Including Zika on the National General Practitioner Competence List of Indonesia is essential to improving this knowledge. 


\section{Conflicts of interest}

No potential conflict of interest relevant to this article was reported.

\section{References}

1. Macnamara FN. Zika virus: a report on three cases of human infection during an epidemic of jaundice in Nigeria. Trans R Soc Trop Med Hyg. 1954;48:139-145.

2. Duffy MR, Chen TH, Hancock WT, et al. Zika virus outbreak on yap island, Federated States OF Micronesia. N Engl J Med. 2009;360:2536-2543.

3. Musso D, Gubler DJ. Zika virus. Clin Microbiol Rev. 2016;29:487-524.

4. Samarasekera U, Triunfol M. Concern over Zika virus grips the world. Lancet. 2016;387:521-524.

5. Hennessey M, Fischer M, Staples JE. Zika Virus Spreads to New Areas - Region of the Americas, May 2015-January 2016. MMWR Morb Mortal Wkly Rep. vol. 65. 2016; 2016:55-58.

6. WHO. Situation Report: Zika Virus, Microcephaly, Guillain-barré Syndrome. World Health Organization; 2017. Available from: http://apps.who.int/iris/bitstream/ 10665/206311/1/zikasitrep_12May2016_eng.pdf?ua=1 Accessed: 2017 19/12.

7. Olson JG, Ksiazek TG, Suhandiman Triwibowo. Zika virus, a cause of fever in Central Java, Indonesia. Trans R Soc Trop Med Hyg. 1981;75:389-393.

8. Olson JG, Ksiazek TG, Gubler DJ, et al. A survey for arboviral antibodies in sera of humans and animals in Lombok, Republic of Indonesia. Ann Trop Med Parasitol. 1983;77:131-137

9. Kwong JC, Druce JD, Leder K. Case report: Zika virus infection acquired during brief travel to Indonesia. Am J Trop Med Hyg. 2013;89:516-517.

10. Leung GH, Baird RW, Druce J, Anstey NM. Zika virus infection in Australia following a monkey bite in Indonesia. Southeast Asian J Trop Med Publ Health. 2015;46:460-464.

11. Perkasa A, Yudhaputri F, Haryanto S, et al. Isolation of Zika virus from febrile patient, Indonesia. Emerg Infect Dis. 2016;22:924-925

12. Yudhaputri FA, Trimarsanto H, Perkasa A, et al. Genomic characterization of Zika virus isolated from Indonesia. Virology. 2017;510:248-251.

13. Betancourt-Trejos ML, Narvaez-Maldonado CF, Ortiz-Erazo WF, et al. Healthcare students and workers' knowledge about Zika and its association with microcephaly in two cities of Colombia. Trav Med Infect Dis. 2016;14:283-285.

14. Gokce A, Ozer A, Bentli R, Tekedereli I. Knowledge level of medical students about Zika virus disease in Malatya, an eastern city of Turkey. Eur J Public Health. 2016;26:452.

15. Ibrahim NK, Moshref RH, Moshref LH, Walid JB, Alsati HS. Knowledge and attitudes towards Zika virus among medical students in king abdulaziz university, jeddah, Saudi arabia. J Infect Public Health. 2018;11(1):18-23.

16. Sabogal-Roman JA, Murillo-Garcia DR, Yepes-Echeverri MC, et al. Healthcare students and workers' knowledge about transmission, epidemiology and symptoms of Zika fever in four cities of Colombia. Trav Med Infect Dis. 2016;14:52-54.

17. Gupta N, Randhawa RK, Thakar S, Bansal M, Gupta P, Arora V. Knowledge regarding Zika virus infection among dental practitioners of tricity area (Chandigarh, Panchkula and Mohali), India. Niger Postgrad Med J. 2016;23:33-37.

18. Iqbal M, Lokanayagi S, Rahul R, Sunil K, Tahir M. Knowledge, attitude and perception of Zika virus among healthcare students of medicine, pharmacy and dentistry of Aimst University. Value Health. 2016;19:A484.

19. Cheema S, Maisonneuve P, Weber I, et al. Knowledge and perceptions about Zika virus in a Middle East country. BMC Infect Dis. 2017;17:524.

20. Harapan H, Aletta A, Anwar S, et al. Healthcare workers' knowledge towards Zika virus infection in Indonesia: a survey in Aceh. Asian Pac J Trop Med. 2017;10:189-194.

21. Harapan H, Utomo P, Anwar S, et al. Knowledge and attitude towards pregnancyrelated complications of Zika virus infection among general practitioners in Indonesia. BMC Infect Dis. 2018 (submitted).

22. Harapan H, Alleta A, Anwar S, et al. Attitudes towards Zika virus infection among medical doctors in Aceh province, Indonesia. J Infect Public Health. 2018;11:99-104.

23. Harapan H, Mudatsir M, Yufika A, et al. Community Acceptance and Willingness-to-pay for a Hypothetical Zika Vaccine: A Cross-sectional Study in Indonesia. Vaccine; 2018 (submitted).

24. Harapan H, Mudatsir M, Yufika A, et al. Willingness to Participate and Associated Factors in a Zika Vaccine Trial in Indonesia: A Cross-sectional Study. Viruses. 2018;10(11):E648.

25. Indonesian Medical Council. Standar Kompetensi Dokter Indonesia. Jakarta: Indonesian Medical Council; 2006.

26. Kaufman DM. Applying educational theory in practice. Br Med J. 2003;326:213-216.

27. Yardley S, Teunissen PW, Dornan T. Experiential learning: AMEE guide No. 63. Med Teach. 2012;34:E102.

28. Janiga J. Does clinical experience influence medical knowledge on eobstetric and gynecology clerkships? Obstet Gynecol. 2015;125 38S-9S.

29. Ministry of Health Republic of Indonesia. Pertanyaan Seputar Penyakit Virus Zika. 2016; 2016. Available from: http://www.depkes.go.id/article/view/16012800001/ pertanyaan-seputar-penyakit-virus-zika.html Accessed: 2017 12/02.

30. Presiden Republik Indonesia. Undang-undang Praktik Kedokteran No. 29 Tahun 2004 Jakarta. 2004; 2004.

31. Cervero RM, Gaines JK. The impact of CME on physician performance and patient health outcomes: an updated synthesis of systematic reviews. $J$ Continuing Educ Health Prof. 2015;35:131-138.

32. Davis D, O'Brien MA, Freemantle N, Wolf FM, Mazmanian P, Taylor-Vaisey A. Impact of formal continuing medical education: do conferences, workshops, rounds, and other traditional continuing education activities change physician behavior or health care outcomes? JAMA. 1999;282:867-874. 